\title{
KNOWLEDGE MANAGEMENT IN PUBLIC ADMINISTRATION OF EDUCATION, SCIENCE AND TECHNOLOGY IN NORTHEAST BRAZIL ${ }^{1}$
}

http://dx.doi.org/10.5902/2318133841954

\author{
Gustavo Moura Cavalcanti² \\ Lydia Maria Pinto Brito ${ }^{3}$ \\ Ahiram Brunni Cartaxo de Castro ${ }^{4}$ \\ Arthur William Pereira da Silva ${ }^{5}$
}

\begin{abstract}
The objective of this study was to analyze the managers' view on education about Knowledge Management in a public institution of education, science and technology in Northeastern Brazil. This is a basic case study investigation and a qualitative research. The reference frameworks used were the knowledge management diagnosis, suggested by Bukowitz and Williams (2002), and the indexes recommended by Brito, Oliveira and Castro (2012). The results showed that Knowledge Management is in a maturation process in the institution researched. The Obtain and Use sections support the positive performance in the tactic processes, and the Build/Keep and Disposal sections support the strategic process. On the other hand, the results indicate that the organization should invest in the development of the sections Learn, which deals with the connection between organizational strategy and the learning derived from everyday actions, and in the Contribute section of the tactical process, as the organization must encourage its professionals contribute with the knowledge you have. In the strategic process, the organization should invest in the Evaluate section of the DGC, as it is up to the organization to identify new forms of organizational capital that can add value so that it can adapt to changes in the macro environment.

Key-words: knowledge management; public administration; education; science; technology.
\end{abstract}

\section{GESTÃO DO CONHECIMENTO NA ADMINISTRAÇÃO PÚBLICA DE EDUCAÇÃO, CIÊNCIA E TECNOLOGIA NO NORDESTE DO BRASIL}

\section{Resumo}

O objetivo deste estudo foi analisar a percepção dos gestores em educação sobre a gestão do conhecimento numa instituição pública de educação, ciência e tecnologia do Nordeste do Brasil. Trata-se de uma pesquisa qualitativa com modo de investigação no estudo de caso. Os referenciais utilizados foram o diagnóstico da gestão do conhecimento, proposto por Bukowitz e Williams (2002), e os indicadores recomendados por Brito, Oliveira e Castro (2012). Os resultados

\footnotetext{
1 This study was financed in part by the Coordenação de Aperfeiçoamento de Pessoal de Nível Superior.

2 Federal Institute of Education, Science and Technology of Rio Grande do Norte, Brazil. E-mail: gustavo.moura@ifrn.edu.br.

3 University Potiguar, Brazil. E-mail: Iydiampbrito@yahoo.com.br.

4 Federal Institute of Education, Science and Technology of Rio Grande do Norte, Brazil. E-mail: brunnicastro@hotmail.com.

5 Federal Institute of Education, Science and Technology of Ceará, Brazil. E-mail: arthurwilliamadm@hotmail.com.

\begin{tabular}{|l|l|l|l|l|l|} 
Regae: Rev. Gest. Aval. Educ. & Santa Maria & v. 9 & n. 18 & Pub. contínua 2020 & p. 1-21
\end{tabular}
}


indicaram que: a GC está em maturação na instituição investigada. O desempenho positivo foi suportado pelos processos táticos nas seções Obtenha e Utilize e, no processo estratégico, pelas seções Construir, Manter e Descartar. Por outro lado, os resultados sinalizaram que a organização deve investir no desenvolvimento das seções Aprenda, que trata da ligação entre a estratégia organizacional e a aprendizagem derivada das ações cotidianas, e na seção Contribua do processo tático, pois a organização deve estimular as pessoas contribuam com o conhecimento que tem. Já no processo estratégico, a organização deve investir na seção Avalie do DGC, pois impende que a organização identifique formas novas de capital organizacional que poderão agregar valor para que ela se adapte as mudanças do macroambiente.

Palavras-chave: gestão do conhecimento; administração pública; educação; ciência; tecnologia. 


\section{Introduction}

The current scenario is characterized by a quick scientific and technological evolution. These are times of micro-structural disruption and quick changes in the macro-environment, which triggers instability and times of fear (Bauman, 2010).

In order to survive in this scenario, the organizations have developed new models in a drill of search for change - from Taylorism-Fordism to the organic, virtual, network-based organizations -, including Knowledge Management. The core of this model is the tacit knowledge creation and transfer, which can add value to products and services, to the decision taking processes and to society innovation (Freire et al., 2016; Nonaka; Takeuchi, 2004). KM enables knowledge identification, acquisition, use, learning, spread, administration and evaluation, which might enable the organizations' maintenance in the search for innovation (Donate; Pablo, 2015; Cardoso; Meireles; Peralta, 2012).

However, there are several barriers to overcome so that the organizations take advantage of this model, such as: the organizations must develop a cultural process of knowledge sharing, they need to create teams for knowledge acquisition, use, creation and transfer (Bashouri; Duncan, 2014), they need to develop roles - specialists - in order to acquire knowledge (Oliveira; Castro; Brito, 2016; Bukowitz; Williams, 2002), they need to design a structure based on new processes and new technologies in order to boost knowledge (Pinho; Rego; Cunha, 2012), they need to favor knowledge property (Serenko, 2013), evaluate and retain people, processes and technologies which contribute to KM, strengthen the relationship with stakeholders and clients (Fidel; Cervera; Schlesinger, 2016), unlearn the knowledge that is not aligned to its essential competency (Schiuma; Andreeva; Kianto, 2012; Bukowitz; Williams, 2002), among others. These barriers apply to both private and public organizations. In the public organization's context, besides the barriers mentioned above, there is the conceptual lethargy the sector has over the topic (Schlesinger et al., 2008) and the challenges to overcome the bureaucratic malfunction.

The public teaching institutions still face their own barriers, such as: they stop facing management drills by designing research projects (Castro et al., 2015), and they avoid knowledge output due to employees' termination and removal.

Due to such barriers, here is the question: how do public managers see Knowledge Management in the tactic and strategic processes from an institution of education, science and technology?

This study aimed at analyzing the managers' view on education about knowledge management in the tactic and strategic processes from a public institution of education, science and technology in Northeastern Brazil.

The teaching institution researched is an institution of professional and technologic education that has been around for over 100 years and whose social role is to offer quality professional and technologic education with a political-pedagogical architecture that is able to articulate science, culture, work and technology - committed to the exercise of citizenship and with knowledge production and socialization, aiming, above all, at transforming real life based on equality (PDI, 2014).

The research is justified by the possibility of raising a systematic KM view through the tactic and strategic processes, for most studies focus (only) on the tactic processes (Donate; Pablo, 2015; Wang; Noe; Wang, 2014; Lee et al., 2013; Alegre; Sengupta; 
Lapiedra, 2013; Pinho; Rego; Cunha, 2012; Schiuma; Andreeva; Kianto, 2012). Besides, most studies on $\mathrm{KM}$ focus on developed countries and, therefore, there are still a few empiric studies about the KM impact on institutions from emerging economies (Schiuma; Andreeva; Kianto, 2012), and these gaps are investigated in this research.

The study will also allow tracing the paths followed by a public institution of education, science and technology in the KM processes, leading to its reflection, for this is the key to understanding the KM achievements, capabilities and resources, and the gaps that allow the organizations to (re)instrument in order to create, convert and spread knowledge (Lee; Kim; Kim, 2012). Besides, this research matters, for KM will be able to support knowledge administration, innovation speed-up, and promote structural promptness and people's mobilization for the adoption of new practices of knowledge spread (Castro; Brito; Varela, 2017).

The KM diagnosis in education can also be relevant to improving social effectiveness (Batista, 2012) of the technologic teaching in Northeastern Brazil. Then, the article brings the theoretical reference, the methodological processes, the results, the discussion, and the study's conclusions, respectively.

\section{A theoretical reference}

In terms of management philosophy, organizational activity and work process, $\mathrm{KM}$ is much disseminated in the academic mainstream (Schiuma; Andreeva; Kianto, 2012), and is especially associated with innovation speed-up and with the organizations' economic performance (Torugsa; O'Donohue, 2016; Al-Hakim; Hassan, 2016).

An example of this $\mathrm{KM}$ dissemination in the organizations comes from the varied formal activities (learning teams, better practices, portals, role plays, among others) and informal activities (informal networks, the sharing of experiences and ideas, talks on the organization, the sharing of solutions to work tasks and issues, an open dialogue, and criticism, among others) that are turned to knowledge sharing, according to Van Waveren, Oerlemans and Pretorius (2017). These practices cause reflections about the organizations' performance in KM (Cardoso; Meireles; Peralta, 2012). Such reflections cause a "set of management activities which allow the companies to deliver value through their knowledge assets" (Schiuma; Andreeva; Kianto, 2012, p. 618) and this delivery takes place when the knowledge processes (creating, sharing, acquiring, transferring, and applying), the infrastructures or management capabilities - business strategies, technologies, policies - are mobilized to bring changes (Cardoso; Meireles; Peralta, 2012).

In this collection, Lee, Kim e Kim (2012) present a concept, in which KM is the management of knowledge infrastructures (technical factors [technologies], structural and cultural factors [normative, reliable and learning-simplification mechanisms] that allow the social capital maximization) and of the knowledge processes - knowledge acquisition, conversion, application, learning, and protection - in the search for an organizational performance for the maintenance and increase of the organizations' performance in the market.

Therefore, $\mathrm{KM}$ is about the construction of a culture that involves $\mathrm{KM}$ policies, technologies, the development of human skills to create and share knowledge, and to develop processes in search for a change, for the organizations' maintenance and performance improvement in the market. 
Several authors have taken turns with contributions that place $\mathrm{KM}$ as a subject in a maturation process (Serenko, 2013). In researches from journals indexed to Scopus and Web of Science ${ }^{T M}$ from the 1990's up to 2017, it was possible to see almost 5 thousand works published over the topic in their title. From these, 45 had "A Model of Knowledge Management" as the descriptor. One of them is Knowledge Management Diagnosis, suggested by Bukowitz and Williams (2002). The authors' model 'takes on the position that there is a process in order to generate, design and obtain value from knowledge. [...] It examines both the process and the environmental circumstances through which the organizations generate wealth from their intellectual capital" (Bukowitz; Williams, 2002, p. 18), and is divided into two process and seven sections: Tactic processes (Obtain, Use, Learn and Contribute sections), which deal with how people get information from their daily work, how they use this knowledge to create value and generate innovation; Strategic processes, which are related to the knowledge evaluation that might be able to keep the organizations manageable in the market in the face of the macro-environment changes, and the knowledge disposal when it adds no more value, according to table 1.

Table 1 -

Knowledge management diagnosis: tactic and strategic processes.

\begin{tabular}{|c|c|}
\hline \multicolumn{2}{|r|}{ Tactic Processes } \\
\hline \multicolumn{2}{|r|}{ Description } \\
\hline Obtain & $\begin{array}{l}\text { It is associated to people's capacity to know how to describe their needs for } \\
\text { information and to know where to find sources of knowledge. The question } \\
\text { associated to this section is: how can this information-digging process become } \\
\text { more efficient? }\end{array}$ \\
\hline Use & $\begin{array}{l}\text { It concerns the use of knowledge to design solutions, for example, for products and } \\
\text { services that must impact the clients' lives. It is the information combination section } \\
\text { of new and interesting ways, and aims at promoting organizational innovation. In } \\
\text { this sense, how can the members of the organization merge information so as to } \\
\text { meet the needs of their clients/beneficiaries exclusively? }\end{array}$ \\
\hline Learn & $\begin{array}{l}\text { It concerns the connection between strategy and learning that comes from the daily } \\
\text { actions, such as: integrating the reflection mechanisms as a daily working habit, } \\
\text { acquiring the benefits of mistakes and failures, and cultivating the art of learning by } \\
\text { doing. The question prompted by this section is: how to develop a socialization } \\
\text { culture and an organizational learning? }\end{array}$ \\
\hline Contribute & $\begin{array}{l}\text { This section assumes that the members of the organization want to contribute with } \\
\text { their knowledge, that the systems and the infrastructures support the contribution } \\
\text { process, and that the organization promotes comprehension and values the } \\
\text { contributed knowledge. The question associated to this section is: how can we } \\
\text { make people share? }\end{array}$ \\
\hline \multicolumn{2}{|r|}{ Strategic Processes } \\
\hline Evaluate & $\begin{array}{l}\text { Evaluation is the section that tries to respond to the macro-environmental changes } \\
\text { since it stops the organization from identifying new ways of organizational capital, } \\
\text { from conceiving new management tasks, and from communicating with the main } \\
\text { stakeholders in order to implement a new set of processes and actions that } \\
\text { evaluate all the niches of knowledge from which the organization generates value. } \\
\text { The question that comes to mind in this section is: how to measure the } \\
\text { performance of the organizational capital that generates value? }\end{array}$ \\
\hline
\end{tabular}




\begin{tabular}{|c|l|}
\hline Build/Keep & $\begin{array}{l}\text { In this section, building is about knowledge cultivation, and keeping is related to the } \\
\text { cultivated knowledge protection. How to develop and implement action plans which } \\
\text { favor the new knowledge and its cultivation that will be able to keep the } \\
\text { organizations innovative and, consequently, manageable in the future? }\end{array}$ \\
\hline Disposal & $\begin{array}{l}\text { This section approaches the need the organizations have to acknowledge the } \\
\text { limited ways of knowledge, to find alternate ways of using this limited knowledge or } \\
\text { discard it. The central question in this section is: how to recognize the knowledge } \\
\text { niches that are useful, overcome the cultural and psychological challenges, and } \\
\text { establish criteria so that the organizations break free from knowledge without } \\
\text { value? }\end{array}$ \\
\hline
\end{tabular}

Source: Brito, Oliveira e Castro (2012); Bukowitz e Williams (2002).

Considering that KMD is the representation of an integrative diagnosis from the KM processes (Lee; Kim; Kim, 2012), this was the model used as one of the reference boards in order to reach this research's objective.

\section{Knowledge Management in the public administration}

KM in the public administration appeared formally only from the year 2000, through a national project coordinated by the Brazilian Institute of Information in Science and Technology (Castro; Brito, 2016), succeeding the moves from the New Public Management (Muzzio; Silva; Rosario, 2013), which features:

The management professionalization in the public organizations; performance patterns and evaluation measures, with objectives that are both measurable and clearly defined; emphasis in control and results; the breakdown of great units from the public sector; the introduction of competitiveness in the public sector; the use of management practices by the private sector; focus on discipline and on the use of resources, reducing costs and searching for a higher efficiency and economy. (Dasso Júnior, 2005, p. 7)

In this sense, for instance, the following were implanted:

I - training: a permanent and deliberate learning process, with the objective to contribute to the development of institutional competencies through the development of individual competencies; II - management through competency: guided training management for the development of a set of knowledge, skills and attitudes that are necessary for the performance of the employees' roles, aiming at reaching the institution's objectives; and III training events: on-site and remote courses, learning while working, formal study groups, exchange programs, internships, workshops and congresses which contribute to the employee's development and which meet the interests of the direct federal public, autarchic and foundational administration. (Brasil, 2006, p. 1)

Among other motivations, the changes that come from the KMD are the fruits of a social control that is more and more demanding (Oliveira, 2015). As much as the need to mitigate the corruption and the bureaucracy dysfunctions, which are, according to Medeiros and Levy (2010), 
the evils that still degenerate the public Brazilian administration. In effect, the public resources' efficient control, with extensions of the mechanisms of participation and social control, and the appreciation of people and of knowledge in the search for administrative innovation and efficiency, are vital components for the construction of a new model of public Brazilian management. (p. 167)

In its core, the public Brazilian management influences several aspects of society, such as education, science and technology. When it is skilled, the public management may contribute to the social transformation and creation of a social capability that is able to agree with a morally balanced and fair society (Oliveira, 2015; Paula, 2015). However, what currently happens in the public Brazilian administration is a crisis of effectiveness and legitimacy which, according to Schlesinger et al. (2008), is caused:

by the mismatch between the State and society, through which the public sector's modus operandi faces itself, acting unfeelingly and impersonally, with no commitment nor public, and highly resistant to changes. A very apparent aspect is that it is only possible to do that which is provided in the Law, and this argument serves as a shield for the non-promotion of changes in a broad sense. (p. 37)

Bergue (2004) states that the process of changes in the public organizations is slower, and Schlesinger et al. (2008) explain that:

most of these organizations still preserve the bureaucratic administration characteristics and can't respond quickly and with quality to the community demands. This type of administration was developed in a different period, when society moved in another pace and the transformations happened more slowly. Thus, it is possible to state that there is currently a shock between the values of the public administration and those of the new economy. The result is the widespread image in society, one that depicts the public administration's inefficiency and poor quality. (p. 6)

Castro and Brito (2016); Batista (2012); Nonaka and Takeuchi (2004) also state that, since the structure in the public service is so hierarchical, knowledge tends to be concentrated to a few people who specialize in a certain task as a strategy of keeping the position, based on accumulated knowledge, since they see it as a lever to be promoted and keep their status quo.

On the other hand, in the NPM's genesis "the procedures adopted for planning in the public sector must focus more on the organizational learning and on the improvement of the governmental managerial capabilities" (Schlesinger et al., 2008, p. 37), and must be based on the management values by competencies and on the knowledge sharing capacity. By this context, one of the barriers to be overcome by the public management is "to guide its strategic actions so as to maximize the organizational knowledge" (p. 36).

From this concept of strategic guidance to maximize the organizational knowledge, that is, to create a culture of knowledge appreciation turned to social learning, it will be possible to enable a Public Societal Administration (Silva; Lima; Gomide, 2017).

Therefore, it is observed that the change that is expected from the public management will not be the result of legislative changes, nor of State reforms, but of a cultural change grounded by knowledge that should involve the public agents and society, 
a cultural change which will be enabled by the employees and public managers' upbringing, suppressing the conceptual lethargy about KM in the public service by the use of practices and by the construction of a $\mathrm{KM}$ infrastructure whose reflection might be commanded by the KMD. Subsequently, here are the research's methodological procedures.

\section{Methodological procedures}

This is a basic qualitative research (Merriam, 2002) that is descriptive as for its purposes, and a study case as for its means.

The realm investigated was composed of 88 managers attached to the Office of Graduate Studies in Administration, and the Boards of Administration from a public institution of Education, Science and Technology in Northeastern Brazil, members of management positions - Executive Position or Bonus Position -, chosen by the researcher's convenience due to the access to the respondents (Cooper; Schindler, 2016). The investigation took place in 22 units of the institution, since it is structured through a multi-campuses chain. The initial estimate was to perform a census but, due to legal reasons, travel issues and/or commitment, $57(64 \%)$ of the managers with more than one year of activity in the position took part in the research. The institution was chosen due to having knowledge in science and technology as its main resource, and due to its social relevance in the professionalization of labor for society. Besides, it is an institution that has been around for over 100 years, with over three thousand employees, among teaching staff and technical-administrative members in education, and around 30 thousand students enrolled in the technical education classes from the stricto sensu post-graduation program.

The technique used for data collection was the structured interview (Merriam, 2002) with the questionnaire suggested by Bukowitz and Williams (2002), which has 140 closedended questions divided into seven sections, each one of them with a list of 20 statements and each statement adopting a scale of gradual answers with a growing intensity from 1 to 3 points, varying between weak (W), moderate (M) and strong (S). The data collection was performed through an electronic form and took place from October to December, 2016.

The data processing was performed through electronic spreadsheets and the data interpretation follows the criterion that says the higher the percentage obtained in the answers, the better the performance of a specific step in the KM process, according to what is anticipated by Bukowitz and Williams (2002). Besides, as guided by the authors, for the calculation of each section and also the average from the seven sections, there is: for the "S"=3, "M"=2 and "W"=1 scores, the "S" total should be added up and multiplied by three: the "M" total should be multiplied by two, and the "W" total should be multiplied by one. The maximum score for each section is 60 points (20 statements $\times 3$ ), whereas the maximum possible general score - for all the sections - is 420 points: 60 points $\times 7$ sections. As an acceptable KM pattern, the authors adopt an average score for each section from $30 \%$ to $70 \%$, and for all the sections of $55 \%$, since these are averages found in the studies performed in the field.

For further analysis of the results in each of the KMD section, the Knowledge Management Indicators were measured according to what was suggested by Brito, Oliveira e Castro (2012). 
Table 2 -

Evaluative research items' distribution according to the Knowledge Management indicators

\begin{tabular}{|c|c|c|c|c|c|c|c|}
\hline KM Indicators & \multicolumn{7}{|c|}{ KMD Sections } \\
\hline & Obtain & Use & Learn & Contribute & Evaluate & Build/Keep & Disposal \\
\hline $\begin{array}{c}\text { Knowledge } \\
\text { management } \\
\text { processes/ } \\
\text { Contextualization/ } \\
\text { Knowledge } \\
\text { management } \\
\text { policy }\end{array}$ & - & - & $\begin{array}{c}1,10,12 \\
15\end{array}$ & $\begin{array}{c}2,12,15 \\
16,18\end{array}$ & $\begin{array}{c}3,4,9 \\
10,13 \\
14,15 \\
17,18 \\
20\end{array}$ & $1,7,16,18$ & $\begin{array}{c}1,2,6,7 \\
10,13,16 \\
17,20\end{array}$ \\
\hline $\begin{array}{l}\text { Knowledge } \\
\text { sharing/ } \\
\text { Communication/ } \\
\text { Relationship }\end{array}$ & $\begin{array}{c}1,2,4 \\
8,9\end{array}$ & $\begin{array}{c}1,5,8 \\
15,18 \\
19\end{array}$ & 19 & $\begin{array}{l}5,7,8,10, \\
11,12,13, \\
14,16,17, \\
18,19,20\end{array}$ & 2,12 & $1,2,19$ & $2,4,9,19$ \\
\hline $\begin{array}{c}\text { Task } \\
\text { accomplishment } \\
\text { capability }\end{array}$ & 15 & - & - & - & - & - & - \\
\hline $\begin{array}{c}\text { Knowledge } \\
\text { management } \\
\text { roles }\end{array}$ & $\begin{array}{c}3,6 \\
10,12, \\
13,18 \\
\end{array}$ & - & - & $1,9,16$ & 14 & 3,10 & 6 \\
\hline $\begin{array}{l}\text { Physical and } \\
\text { organizational } \\
\text { structure }\end{array}$ & & $\begin{array}{c}2,3 \\
11,13 \\
17\end{array}$ & - & $4,8,10$ & - & - & - \\
\hline $\begin{array}{l}\text { Electronic means } \\
\text { and information } \\
\text { technologies }\end{array}$ & $\begin{array}{c}5,7, \\
11,14, \\
16,17\end{array}$ & - & - & 4,10 & - & $\begin{array}{c}2,5,7,11,13 \\
, 17\end{array}$ & - \\
\hline $\begin{array}{l}\text { Paperwork, } \\
\text { results, } \\
\text { measurement/ } \\
\text { protocols and } \\
\text { rules }\end{array}$ & 19,20 & 14 & - & - & $\begin{array}{c}3,4,5,6 \\
7,8,11 \\
12,17 \\
20\end{array}$ & 15,20 & - \\
\hline Decisive process & - & 4 & $\begin{array}{c}2,6,8, \\
17,18,20\end{array}$ & - & 13 & - & $\begin{array}{c}1,3,8,13 \\
14,15\end{array}$ \\
\hline $\begin{array}{c}\text { Role play/ } \\
\text { games/innovation/ } \\
\text { problem } \\
\text { resolution }\end{array}$ & - & $\begin{array}{l}6,8,9 \\
12,20\end{array}$ & $\begin{array}{c}4,11,13 \\
16,20\end{array}$ & - & - & $4,10,14$ & 18 \\
\hline Partnership & - & $\begin{array}{c}7,10 \\
16\end{array}$ & 3,9 & 6 & - & $8,12,18$ & $11,12,19$ \\
\hline $\begin{array}{l}\text { Knowledge } \\
\text { evaluation }\end{array}$ & - & - & $5,7,9,14$ & - & - & - & $5,13,16$ \\
\hline Values & - & - & - & - & - & 6,9 & - \\
\hline $\begin{array}{c}\text { Knowledge } \\
\text { management } \\
\text { appreciation and } \\
\text { valuation }\end{array}$ & - & - & - & $3,17,18$ & $\begin{array}{c}1,16 \\
19\end{array}$ & - & 10,20 \\
\hline
\end{tabular}

Source: adapted from Brito, Oliveira e Castro (2012). 
In order to assess these indicators, the data collected from each research' instrument question were repeated and the average was extracted. According to Costa (2011), the analysis recommendation for the three-point scale case is that an average up to 1.8 is weakly descriptive, and between 1.8 and 2.4 it is moderately descriptive, whereas an average above 2.4 is strongly descriptive. In this sense, Godoy (1995) explains that: "Although the case studies are essentially a qualitative-character research, they can import quantitative data in order to clarify some aspects of the investigated issue. It is important to emphasize that, whenever there is a qualitative analysis, the statistical processing is not refined" (p. 26).

The research's internal validity and reliability were assessed through the area researchers' peer evaluation. The research's external validity lies on the rich and dense description that tried to deeply understand the perception in a group of individuals, avoiding forms of generalization of the findings for the population (Merriam, 2002). Then, there are the KMD results and data discussion.

\section{Results and discussion \\ KM Diagnosis}

Table 3 presents the results obtained from data collection and processing about KMD. Based on the score obtained in each section, it was possible to see that there is an adequacy between the results found with the values raised by Bukowitz and Williams (2002) in field studies, which is marked by a satisfactory KM performance in the institution researched. The initial result by section was ratified by the general average from all the sections (62.91\%), which reached a percentage above the $55 \%$ advocated by the KMD authors. These results show that the organization is facing the changing challenge, as highlighted by Freire et al. (2016); Nonaka and Takeuchi (2004).

Table 3 -

General score result and percentages obtained by section and by cognitive process.

\begin{tabular}{c|c|c|c|c}
\hline Process & Section/Stage & Points & Section Percentage & Performance \\
\hline \multirow{4}{*}{ Tactic } & Obtain & 39.23 & $65.38 \%$ & Better \\
\cline { 2 - 5 } & Use & 39.14 & $65.23 \%$ & Worse \\
\cline { 2 - 5 } & Learn & 37.86 & $63.10 \%$ & \\
\cline { 2 - 5 } & Contribute & 38.11 & $63.51 \%$ & Worse \\
\hline \multirow{3}{*}{ Strategic } & Evaluate & 33.33 & $55.56 \%$ & \\
\cline { 2 - 5 } & Build / Keep & 39.23 & $65.38 \%$ & \\
\cline { 2 - 5 } & Disposal & 37.32 & $62.19 \%$ & Average $=62.91 \%$ \\
\hline
\end{tabular}

Source: research data (2016).

Therefore, from the perception of the managers researched, the institution obtains, uses, learns and contributes to knowledge - tactic processes -, as a way to create value and solve daily, short-term, problems. The results also showed that there is some alignment between the institutional and the $\mathrm{KM}$ strategies, emphasizing the organizational leaderships' roles and the group formation roles that will act as evaluators and knowledge builders which will enable public value in the future.

The Obtain section appeared as the best evaluated one in the tactic process, with $65.38 \%$, and this means that, through people, the institution describes its information 
needs well and knows how to request, understand, communicate, capture and store the information it needs. Then, there is the study deepening through the $\mathrm{KM}$ indicators that explain the results in each KMD Section.

\section{Tactic processes}

From table 4, it was possible to see that, according to the managers in education, the indicators which strongly describe how the researched institution obtains knowledge were: the sharing of knowledge, communication, relationship; the task accomplishment capability; the ;electronic means and information technologies and the paperwork, results, measurement / protocols and rules.

Table 4 -

Knowledge management indicators from the Obtain Section.

\begin{tabular}{|c|c|c|c|c|c|}
\hline \multirow{2}{*}{$\mathrm{KM}$ indicators from the Obtain Section } & \multirow{2}{*}{ Questions } & \multicolumn{3}{|c|}{ Answers } & \multirow{2}{*}{ Average } \\
\hline & & $S$ & $M$ & W & \\
\hline $\begin{array}{l}\text { (Ob1) Knowledge sharing, communication, } \\
\text { relationship }\end{array}$ & $1,2,4,8,9$ & 81 & 159 & 45 & 3.38 \\
\hline (Ob2) Task accomplishment capability & 15 & 17 & 30 & 10 & 3.37 \\
\hline (Ob3) Knowledge management roles & $3,6,10,12,13,18$ & 46 & 180 & 116 & 2.39 \\
\hline $\begin{array}{l}\text { (Ob4) Electronic means and information } \\
\text { technologies }\end{array}$ & $5,7,11,14,16,17$ & 56 & 163 & 66 & 2.89 \\
\hline $\begin{array}{l}\text { (Ob5) Paperwork, results, measurement, } \\
\text { protocols and rules }\end{array}$ & 19,20 & 19 & 66 & 29 & 2.74 \\
\hline
\end{tabular}

Source: research data (2016).

These indicators respectively clarify that the performance in the Obtain Section was due to the institution understanding and communicating the intended use of information to their stakeholders and to other interested parties, and, according to Serenko (2013) and Pinho, Rego and Cunha (2012), this is a challenge that was overcome in the context of the institution researched. Besides, the organization is able to turn its informational environment into a routine and to share information, knowledge, problem solution and successful experiences; the people are able to find the information they need at the moment they are looking for daily problem solutions; the institution also has electronic navigation and capture instruments that lead people to the best pieces of information needed to improve work quality and efficiency; and it keeps structures and processes to document and share information, whether it is centrally generated or individually published.

The KMD Use Section, with an average of $65.23 \%$, shows that the institution researched combines information in new and interesting ways in order to promote the organizational innovation, and that the institution discusses about the use of knowledge for the development of solutions, for instance, for the accomplishment of services or for the taking of decisions which must impact on its beneficiaries' lives, according to table 5 . According to Fidel, Cervera and Schlesinger (2016), these are ways to strengthen the organization's relationship with its beneficiaries. 
Table 5 -

Knowledge management indicators from the Use Section

\begin{tabular}{l|c|c|c|c|c}
\hline \multicolumn{1}{c|}{ KM indicators from the Use Section } & \multirow{2}{*}{ Questions } & \multicolumn{2}{|c|}{ Answers } & \multirow{2}{*}{ Average } \\
\cline { 4 - 6 } & & S & M & W & \\
\hline (Us1) Knowledge sharing, communication, relationship & $\begin{array}{c}1,5,8,15,18, \\
19\end{array}$ & 105 & 145 & 92 & 3.11 \\
\hline (Us2) Physical and organizational structure & $2,3,11,13,17$ & 68 & 160 & 57 & 3.12 \\
\hline $\begin{array}{l}\text { (Us3) Paperwork, results, measurement, protocols and } \\
\text { rules }\end{array}$ & 14 & 9 & 33 & 15 & 2.68 \\
\hline (Us4) Decisive process & 4 & 12 & 28 & 17 & 2.74 \\
\hline (Us5) Role play/games/innovation/problem resolution & $6,8,9,12,20$ & 49 & 141 & 95 & 2.52 \\
\hline (Us6) Partnership & $7,10,16$ & 33 & 96 & 42 & 2.84 \\
\hline
\end{tabular}

Source: research data (2016).

According to table 5, all the indicators were strongly descriptive on their capability of knowledge use by the institution researched. This means that the institution keeps a collaborative environment in the search for work improvement and that its work spaces promote the communication and the knowledge flow between people and groups in order to reach a type of creative use of knowledge; it has a level of confidential information safety protocol; that the institution uses ludic and/or non-structured approaches which favor the creative thinking of daily organizational problem solution; and that it tries to overcome the organizational limits through the collaboration from beneficiaries, suppliers and partners as a pre-requirement to produce common gains of competencies and competitiveness.

The Learn Section presented the worst performance in the tactic process, with $63.10 \%$. Even though, the result shows that the institution fosters actions turned to individual and organizational learning, whether formal (Van Waveren; Oerlemans; Pretorius, 2017) or informal (Cardoso; Meireles; Peralta, 2012), integrating them into every day's ordinary and habitual work, according to table 6 , below.

Table 6 -

Knowledge management indicators from the Learn Section.

\begin{tabular}{l|c|c|c|c|c}
\hline \multicolumn{1}{c|}{ KM indicators from the Learn Section } & \multirow{2}{*}{ Questions } & \multicolumn{2}{c|}{ Answers } & \multirow{2}{*}{ Average } \\
\cline { 3 - 5 } $\begin{array}{l}\text { (Le1) Knowledge management } \\
\text { processes/contextualization/ } \\
\text { knowledge management policy }\end{array}$ & $1,10,12,15$ & 34 & 126 & 68 & 2.55 \\
\hline (Le2) Knowledge sharing, communication, relationship & 19 & 13 & 36 & 8 & 3.26 \\
\hline (Le3) Decisive process & $2,6,8,17,18$, & 60 & 188 & 94 & 2.70 \\
\hline (Le4) Role play, games, innovation, problem resolution & $4,11,13,16,20$ & 59 & 147 & 79 & 2.79 \\
\hline (Le5) Partnership & 3,9 & 15 & 57 & 42 & 2.29 \\
\hline (Le6) Knowledge evaluation & $5,7,9,14$ & 44 & 121 & 63 & 2.75 \\
\hline Source: Researn
\end{tabular}

Source: Research data (2016).

The indicators that describe how the researched organization learns are: knowledge sharing, communication, relationship; role play; games; innovation; problem resolution; 
knowledge evaluation; decisive process and knowledge management processes, contextualization, knowledge management policy. Respectively, this means that:

a) In the institution researched, people are able to interact with each other in the search for relevant information, thus favoring the culture of partnership, responsibility, egalitarianism, cooperation and complementarity, no matter their hierarchical level;

b) There is the use of games and role plays to better understand how things take place in the organizational context, and to use past experiences about the collective impression in order to predict future actions and favor mutual learning;

c) There is room for reflection about work experiences and about the knowledge learned as an indispensable way to set the organizational system, making it more effective and efficient;

d) There is the use of redundant mind and decision taking models to better understand how things take place in a certain way and learn how to solve different issues; and,

e) In the organization, the experience mistakes, failures, problems and disagreements are opportunities to learn as a way to rebuild the $\mathrm{KM}$ processes in the organizational environment.

On the other hand, the results from the Contribute Section (63.51\%), according to table 7, showed that the institution fosters actions that encourage the employees to share tacit knowledge, since this is the core of individual and organizational learning and of the organizational knowledge creation (Nonaka; Takeuchi, 2004).

Table 7 -

Knowledge management indicators from the contribute section.

\begin{tabular}{|c|c|c|c|c|c|}
\hline \multirow{2}{*}{$\mathrm{KM}$ indicators from the contribute section } & \multirow{2}{*}{ Questions } & \multicolumn{3}{|c|}{ Answers } & \multirow{2}{*}{ Average } \\
\hline & & $\mathrm{S}$ & $\mathrm{M}$ & W & \\
\hline $\begin{array}{l}\text { (Co1) Knowledge management } \\
\text { processes/Contextualization/Knowledge } \\
\text { management policy }\end{array}$ & $2,12,15,16,18$ & 36 & 156 & 93 & 2.40 \\
\hline $\begin{array}{l}\text { (Co2) Knowledge } \\
\text { sharing/Communication/Relationship }\end{array}$ & $\begin{array}{l}5,7,8,10,11 \\
12,13,14,16 \\
17,18,19,20\end{array}$ & 117 & 416 & 208 & 2.63 \\
\hline (Co3) Knowledge management roles & $1,9,16$ & 35 & 106 & 30 & 3.09 \\
\hline (Co4) Physical and organizational structure & $4,8,10$ & 38 & 96 & 37 & 3.02 \\
\hline $\begin{array}{l}\text { (Co5) Electronic means and information } \\
\text { technologies }\end{array}$ & 4,10 & 29 & 59 & 26 & 3.08 \\
\hline (Co6) Partnership & 6 & 11 & 30 & 16 & 2.74 \\
\hline $\begin{array}{l}\text { (Co7) Knowledge management appreciation and } \\
\text { valuation }\end{array}$ & $3,17,18$ & 21 & 105 & 45 & 2.58 \\
\hline
\end{tabular}

Source: research data (2016).

Through data analysis, it is possible to see that the indicators which positively support the Contribute Section performance were: knowledge management roles; electronic means and information technologies; physical and organizational structure; partnership; knowledge sharing, communication, relationship and knowledge management appreciation and valuation. 
From the perception of the education managers, these results indicate that the organization has people who are able to monitor the virtual network contents by helping others to better express what they know; it has information technologies that are able to contribute to the information storage and direction; and it has an organizational structure of people, groups and information technologies that are able to connect with the knowledge stored so that it can guide people's contributions. Therefore, the organization was able to format a structure to improve the communications and the knowledge flows internally (Pinho; Rego; Cunha et al., 2012). Besides, the people from the organization take part in multiple communities, thus promoting knowledge dissemination, which is an overcome challenge (Bashouri; Duncan, 2014); and the organization values people who contribute to the knowledge that can generate public value.

In the tactic processes analysis, three indicators represent barriers the organization must overcome and which are the key to reaching performance excellence in KM. They are: (Ob3) Knowledge management roles, (Ap5) Partnership and (Ct1) Knowledge management processes, contextualization, knowledge management policy, for, from the managers' perception in education, the institution moderately arranges individuals and specific groups that are able to judge, identify, collect, classify, summarize and spread the organizational knowledge by articulating between the information needs and the information databases, and narrowing the information options up to the best of the best. Besides, the institution moderately overcomes the organizational limits with the collaboration with its beneficiaries and suppliers as a pre-requirement to produce mutual learning.

\section{Strategic processes}

The Evaluate Section presented the worst performance in the strategic process, with $55.56 \%$. This result might show that the institution barely defined the knowledge that is necessary for its social function and barely mapped the existing intellectual capital, against its future needs.

Through the KM indicators, and according to table 8, it was possible to see that the strongest knowledge evaluation descriptors were: knowledge management appreciation and valuation and knowledge management roles, which are related to the organization's capability to appreciate knowledge as a resource that is able to generate value and to introduce managers who are able to evaluate the necessary knowledge when they allocate resources for the innovation processes, respectively. The latter result supports what was stated by Oliveira, Castro and Brito (2016), when they say that the organizations must use specialists as filters of relevant information.

Table 8 -

Knowledge management indicators in the strategic processes.

\begin{tabular}{|c|c|c|c|c|c|c|c|c|}
\hline \multicolumn{9}{|c|}{ Evaluate section } \\
\hline \multirow{2}{*}{\multicolumn{3}{|c|}{ KM Indicators }} & \multirow{2}{*}{\multicolumn{2}{|c|}{ Questions }} & \multicolumn{3}{|c|}{ Answers } & \multirow{2}{*}{ Average } \\
\hline & & & & & $\mathrm{F}$ & $\mathrm{M}$ & $\mathrm{Fr}$ & \\
\hline \multicolumn{3}{|c|}{$\begin{array}{l}\text { (Ev1) Knowledge management } \\
\text { processes/Contextualization/ } \\
\text { Knowledge management policy }\end{array}$} & \multicolumn{2}{|c|}{$\begin{array}{c}3,4,9,10,13,14 \\
15,17,18,20\end{array}$} & 68 & 259 & 243 & 2.08 \\
\hline \multicolumn{3}{|c|}{ (Ev2) Knowledge sharing/Communication/Relationship } & & & 9 & 43 & 62 & 1.61 \\
\hline Regae: Rev. Gest. Aval. Educ. & Santa Maria & v. 9 & n. 18 & Pub. con & ua 20 & & p. 1 & \\
\hline
\end{tabular}




\begin{tabular}{|c|c|c|c|c|c|}
\hline (Ev3) Knowledge management roles & 14 & 7 & 34 & 16 & 2.53 \\
\hline $\begin{array}{l}\text { (Ev4) Paperwork, results, measurement/protocols and } \\
\text { rules }\end{array}$ & $\begin{array}{c}3,4,5,6,7,8,11 \\
12,17,20\end{array}$ & 62 & 234 & 274 & 1.88 \\
\hline (Ev5) Decisive process & 13 & 7 & 26 & 24 & 2.11 \\
\hline $\begin{array}{l}\text { (Ev6) Knowledge management appreciation and } \\
\text { valuation }\end{array}$ & $1,16,19$ & 36 & 76 & 59 & 2.60 \\
\hline
\end{tabular}

\begin{tabular}{|c|c|c|c|c|c|}
\hline \multicolumn{6}{|c|}{ Build/Keep section } \\
\hline $\begin{array}{l}\text { (Bk1) Knowledge management } \\
\text { processes/Contextualization/ } \\
\text { Knowledge management policy }\end{array}$ & $1,7,16,18$ & 30 & 126 & 72 & 2.45 \\
\hline (Bk2) Knowledge sharing/Communication/Relationship & $1,2,19$ & 23 & 101 & 47 & 2.58 \\
\hline (Bk3) Knowledge management roles & 3,10 & 25 & 49 & 40 & 2.61 \\
\hline (Bk4) Electronic means and information technologies & $2,5,7,11,13,17$ & 102 & 169 & 71 & 3.27 \\
\hline $\begin{array}{l}\text { (Bk5) Paperwork, results, measurement/protocols and } \\
\text { rules }\end{array}$ & 15,20 & 25 & 65 & 24 & 3.03 \\
\hline (Bk6) Role play/games/innovation/problem resolution & $4,10,14$ & 23 & 92 & 56 & 2.42 \\
\hline (Bk7) Partnership & $8,12,18$ & 20 & 106 & 45 & 2.56 \\
\hline (Bk8) Values & 6,9 & 20 & 70 & 24 & 2.89 \\
\hline \multicolumn{6}{|c|}{ Disposal section } \\
\hline $\begin{array}{l}\text { (Di1) Knowledge management } \\
\text { processes/Contextualization/Knowledge management } \\
\text { policy }\end{array}$ & $\begin{array}{l}1,2,6,7,10,13 \\
16,17,20\end{array}$ & 86 & 267 & 160 & 2.57 \\
\hline (Di2) Knowledge sharing/Communication/Relationship & $2,4,9,19$ & 57 & 121 & 50 & 3.09 \\
\hline (Di3) Knowledge management roles & 6 & 5 & 32 & 20 & 2.21 \\
\hline (Di4) Decisive process & $1,3,8,13,14,15$ & 62 & 176 & 104 & 2.63 \\
\hline (Di5) Role play/games/innovation/problem resolution & 18 & 14 & 34 & 9 & 3.26 \\
\hline (Di6) Partnership & $11,12,19$ & 27 & 87 & 57 & 2.47 \\
\hline (Di7) Knowledge evaluation & $5,13,16$ & 24 & 97 & 50 & 2.54 \\
\hline (Di8) Knowledge management appreciation and valuation & 10,20 & 22 & 49 & 43 & 2.45 \\
\hline
\end{tabular}

Source: research data (2016).

The decisive process, knowledge management processes, contextualization, knowledge management policy and ,paperwork, results, measurement, protocols and rules indicators moderately describe the institution's behavior in knowledge evaluation. It means that, with some limitation, there is the use of solid facts, number and non-measurable pieces of information as a support for the decisions based on knowledge; there is the KM measurement and processes flow description so that the institution understands what it is trying to generate; and knowledge is measured through qualitative and quantitative actions in order to dimension the effectiveness and to issue a movement document on $\mathrm{KM}$ in the institution researched.

On the other hand, the "knowledge sharing / communication / relationship" indicator presented the worst performance, for the institution does not describe nor discuss about $\mathrm{KM}$ in order to produce reports on this management's quality.

Regarding the KMD's Build/Keep section, it presented the best performance $(65.38 \%)$ in the strategic process, showing that the institution researched has strategies to foster knowledge development, and protects and nurtures knowledge along with its social function.

With further analysis, and according to table 8 , it was possible to state that the variables which mostly contributed to this section's positive performance were electronic

\begin{tabular}{|l|l|l|l|l|r|r|}
\hline Regae: Rev. Gest. Aval. Educ. & Santa Maria & v. 9 & n. 18 & Pub. contínua 2020 & p. 1-21
\end{tabular}


means and information technologies, paperwork, results, measurement, protocols and rules, values, knowledge management roles, knowledge sharing, communication, relationship and partnership. These indicators show that:

a) The information technologies have knowledge that is considered reliable about the researched organization's expertise so that its managers may take long-term decisions;

b) The maintenance of the educational services happens through the added value that knowledge has;

c) People are considered as valuable by the competencies they have and there is some organizational effort to align the individual formal and informal values with those of the organization;

d) Individuals or specific groups are appointed to lead the KM effort;

e) People know when it is not appropriate to share knowledge externally, whereas, internally, knowledge communication is an action that anyone in the organization may benefit from; and,

f) Strategic relationship networks are built with other organizations and with the beneficiaries by sharing technologies and ideas in order to promote innovative educational services for the market. Besides, the organization invests in networking and nurtures reliability so that these relationships may work.

On the other hand, the role play, games, innovation, problem resolution and knowledge management processes, contextualization, knowledge management policy variables still represent barriers, for they show that the institution researched moderately encourages people to think about building innovative ideas in educational services from non-functional activities and, just as intensely, the institution, through information and communication technologies, fosters the creation of different people networks to boost knowledge through long-lasting relationships, and keeps people with indispensable knowledge for its social function in the institution.

The Disposal Section, which deals with discarding the knowledge that is not important, neither in the present nor in the future, in order to free time and resources to increase and keep that - knowledge - which is strategically important for the organization (Brito; Castro, 2014; Bukowitz; Williams, 2002), showed a percentage of $62.19 \%$, which reveals an acceptable $\mathrm{KM}$ pattern in this section.

According to table 8, the $\mathrm{KM}$ indicators, which supported the positive result in this section, were: role play, games, innovation, problem resolution; knowledge sharing, communication, relationship; decisive process; knowledge management processes, contextualization, knowledge management policy and knowledge evaluation. These indicators show that the institution researched prefers to use the resources, the skills and the initiatives locally built in order to test or enable new ideas linked to education, which is one of the Public Societal Administration's characteristics (Silva; Lima; Gomide, 2017).

Furthermore, the indicators also show that (i) the organization is able to understand the impact of the relationships on productivity before the automatization of tasks; (ii) it treats the affected people with dignity and respect to keep the knowledge basis intact; (iii) it thinks about how high it can promote the knowledge acquired; (iv) it discards knowledge in a planned way; ( $v$ ) it refuses works if they don't build knowledge that adds to the 
organization; (vi) it outsources skills which do not support its social role; (vii) it tries to follow activities of higher value or tries to allocate people to the right skills and expertise before dismissing them from a project; and (viii) it evaluates if the knowledge built can be used in different ways or discarded with its components, according to what was advocated by Schiuma, Andreeva and Kianto (2012) and Bukowitz and Williams (2002).

Regarding the indicators that still represent barriers on a moderate level, they were: knowledge management roles, partnership and knowledge management appreciation and valuation. This means that the institution researched moderately takes part in groups of research about its operation field by helping to decide the need for knowledge acquisition, and it creates bonds with other organizations with the inclusion of people as apprentices in other similar institutions to determine the need for new knowledge acquisition or expertise to keep its knowledge base updated.

\section{Conclusions}

Considering the objective of this research, and through the results, it was possible to see that, in the organization studied, even though it is over one hundred years old and creates knowledge by nature, it still has Knowledge Management as a model in a maturing process, since it reached averages classified as moderate, similar to the ones found in organizations that had tested the KMD in the field. The Obtain and Use sections supported the organizations positive performance in the tactic processes; and the Build/Keep and Disposal sections, in the strategic process. This means the organization must focus on the development of KM and on its practices on the tactic process' Learn and Contribute sections, which deal with individual and organizational learning in order to increase the efficiency and the innovation in future projects by sharing knowledge; and the strategic process' Evaluate section, which deals with the necessary knowledge evaluation and performance for the social role in the institution researched, in contrast with the future needs of knowledge.

Generally speaking, it is possible to see that there is some effort from the organization to consolidate the Taylorism-Fordism change for the learning organizations, and that it stopped facing the management drill through the accomplishment of pedagogical projects, for it built an infrastructure of people, processes and technologies to store knowledge about its operation field, keeps formal and informal, internal and external networks of experience and ideas sharing, uses management practices from the private sector, shares solutions to tasks and work-related problems so that everyone benefits, among others. These results are preceded by the organization's capacity to prepare citizens and partners to act in favor of the State upon designing and implementing policies of education, science and technology; to promote social insertion; to reduce social inequalities; and some level of quality of life for its beneficiaries, besides labor preparation for the market.

The appreciation of people and knowledge in the search for innovation and for the administrative efficiency are also components that positively influence in the process of change that matures in the organization, and this indicates the overcome of the efficacy and legitimacy crisis caused by the public management models previous to the New Public Management and the Public Societal Administration. 
The further KMD also allowed discussing which $\mathrm{KM}$ indicators were moderately and weakly descriptive in the model, which are: (Bk1) (Le1) Knowledge management processes / Contextualization / Knowledge management policy; (Bk6) Role play / games / innovation / problem resolution; (Le2) Knowledge sharing / Communication / Relationship; (Le4) Paperwork, results, measurement / protocols and rules; (Le5) Decisive process; (Di3) Knowledge management roles; (Di6) Partnership; and, (Di8) KM appreciation and valuation. Therefore, these indicators represent the barriers the organization has in order to consolidate $\mathrm{KM}$ as a model of reference for education, science and technology in Northeastern Brazil. Identifying these indicators creates an opportunity of reflection for the managers in education about its consequences for society. Besides, it shows the need for KM practices development which enables the combination of the intellectual with the strategic demands, for most of these indicators can be found in the strategic processes.

As this study's limitations, the data were collected from only one sample in Northeastern Brazil and, therefore, their findings can't be inserted into other contexts. The research is also limited to data triangulation, which made the researchers return to those researched in order to identify, from the subjectivity established in the managers' activity, the obstacles for them to overcome the barriers that still remain in the search for the KM model consolidation which enables a transforming public social action.

The suggestions for future works lie in comparative empiric studies with public institutions from other Brazilian States or from other countries with similar characteristics, and longitudinal studies with data triangulation in order to overcome the single-method limitations.

\section{References}

ALEGRE, Joaquín; SENGUPTA, Kishore; LAPIEDRA, Rafael. Knowledge management and innovation performance in a high-tech SMEs industry. International Small Business Journal, v. 31, n. 4, 2013, p. 454-470.

SCHIUMA, Giovanni; ANDREEVA, Tatiana; KIANTO, Aino. Does knowledge management really matter? Linking knowledge management practices, competitiveness and economic performance. Journal of Knowledge Management, v. 16, n. 4, p. 617-636, 2012.

BAUMAN, Zygmunt. Capitalismo parasitário: e outros temas contemporâneos. Rio de Janeiro: Zahar, 2010.

BASHOURI, Joseph; DUNCAN, Glen William. Communities of practice: linking knowledge management and strategy in creative firms. Journal of Business Strategy, v. 35, n. 6, p. 49-57, 2014.

BATISTA, Fábio Ferreira. Modelo de gestão do conhecimento para a administração pública brasileira: como implementar a gestão do conhecimento para produzir resultados em benefício do cidadão. Brasília: Ipea, 2012.

BERGUE, Sandro Trescastro. Gestão estratégica de pessoas no setor público. São Paulo: Atlas, 2014.

BUKOWITZ, Wendi; WILLIAMS, Ruth. Manual de Gestão do Conhecimento: ferramentas e técnicas que criam valor para a empresa. Porto Alegre: Bookman, 2002.

BRASIL. Decreto $n^{\circ}$ 5.707, de 23 de fevereiro de 2006. Dispõe sobre a Política Nacional de Desenvolvimento de Pessoal da Administração Pública Federal. Diário Oficial da 
República Federativa do Brasil, Poder Executivo, Brasília, DF, 24 fevereiro. Seção 1, 135137, 2006.

BRITO, Lydia Maria Pinto; CASTRO, Ahiram Brunni Cartaxo de. Descarte do Conhecimento como estratégia de inovação: um estudo em uma instituição pública de educação não-formal do Nordeste do Brasil. Holos, Natal, v. 30, n. 4, 2014, p. 397-414.

BRITO, Lydia Maria Pinto; OLIVEIRA, Patrícia Webber Souza de; CASTRO, Ahiram Brunni Cartaxo de. Gestão do conhecimento numa instituição pública de assistência técnica e extensão rural do Nordeste do Brasil. Revista de Administração Pública, Rio de Janeiro, v. 46, n. 5, 2012, p. 1341-1366.

CARDOSO, Leonor; MEIRELES, Andreia; PERALTA, Carlos Ferreira. Knowledge management and its critical factors in social economy organizations. Journal of Knowledge Management, v. 16, n. 2, p. 267-284, 2012.

CASTRO, Ahiram Brunni Cartaxo de; BRITO, Lydia Maria Pinto; VARELA, Jedídja Hadassa de Santana. A ressignificação da área de gestão de pessoas e os novos papéis das pessoas e das organizações. Holos, Natal, v. 33, n. 4, 2017, p. 408-423.

CASTRO, Ahiram Brunni Cartaxo de Castro; BRITO, Lydia Maria Pinto Brito. Gestão do Conhecimento: como as organizações públicas do Brasil percebem esse modelo? Revista Gestão Industrial, Ponta Grossa, v. 12, n. 2, 2016, p. 59-72.

CASTRO, Ahiram Brunni Cartaxo de; BRITO, Lydia Maria Pinto; SANTOS, Rosineide Silva dos; Varela, Jedídja Hadassa de Santana. O planejamento estratégico como ferramenta para a gestão escolar: Um estudo de caso em uma instituição de ensino filantrópica da Bahia/BA. Holos, Natal, v. 31, n. 2, 2015, p. 195-211.

COOPER, Donald; SCHINDLER, Pamela. Métodos de pesquisa em administração. Porto Alegre: McGraw Hill Brasil, 2016.

COSTA, Francisco José da. Mensuração e desenvolvimento de escalas: aplicações em administração. Rio de Janeiro: Ciência Moderna, 2011.

DASSO JÚNIOR, Aragon Érico. A nova gestão pública (NGP): a teoria da administração pública do estado neoliberal. Porto Alegre: UBRS, 2005.

DONATE, Mario Javier; PABLO, Jesús David Sánchez de. The role of knowledge-oriented leadership in knowledge management practices and innovation. Journal of Business Research, v. 68, n. 2, 2015, p. 360-370.

FIDEL, Pilar; CERVERA, Amparo; SCHLESINGER, Walesska. Customer's role in knowledge management and in the innovation process: effects on innovation capacity and marketing results. Knowledge Management Research \& Practice, v. 14, n. 2, 2016, p. 195203.

FREIRE, Patrícia de Sá et al. Universidade corporativa em rede: considerações iniciais para um novo modelo de educação corporativa. Espacios, Caracas v. 37, n. 5, 2016.

GODOY, Arilda Schmidt. Introdução à pesquisa qualitativa e suas possibilidades. Revista de Administração de Empresas, São Paulo, v. 35, n. 2, 1995, p. 57-63.

LEE, Sangjae; KIM, Byung Gon; KIM, Hoyal. An integrated view of knowledge management for performance. Journal of Knowledge Management, v. 16, n. 2, 2012, p. 183-203. 
LEE, Voon-Hsien; LEONG, Lai-Ying; HEW, Teck-Soon; Oll, Keng-Boon. Knowledge management: a key determinant in advancing technological innovation?. Journal of Knowledge Management, v. 17, n. 6, 2013, p. 848-872.

MEDEIROS, Paulo César; LEVY, Evelin e Autores. Construindo uma nova gestão pública: Coletânea de textos do I Ciclo de palestra organizado pela escola de governo do RN. Natal: SEARH/RN, 2010.

MERRIAM, Sharan. Qualitative research in practice: examples for discussion and analysis. San Francisco: Jossey-Bass Inc Pub., 2002.

MUZZIO, Henrique; SILVA, Greg Jordan Alves; ROSARIO, Soraya Andrea Figueiredo do. O governo em 3D-patrimonialismo, burocracia e nova gestão pública: uma análise da percepção de servidores públicos municipais. Revista Brasileira de Gestão e Desenvolvimento Regional, Taubaté, v. 9, n. 3, 2013, p. 205-226.

NONAKA, Ikujiro; TAKEUCHI, Hirotaka. Criação de conhecimento na empresa. São Paulo: Elsevier Brasil, 2004.

OLIVEIRA, Josicleide Alves de; CASTRO, Ahiram Brunni Cartaxo de; BRITO, Lydia Maria Pinto. Gestão do Conhecimento: um estudo em um hospital federal universitário do Nordeste do brasil. Revista Gestão \& Conhecimento, Belo Horizonte, v. 10, n. 2, 2016, p. 1-29.

OLIVEIRA, Dalila Andrade. New public management and popular-democratic governments: contradictions between the pursuit for efficiency and the expansion of the right to education. Educação \& Sociedade, São Paulo, v. 36, n. 132, 2015, p. 625-646.

PAULA, Ana Paulo Paes de. Por uma nova gestão pública. Rio de Janeiro: FGV, 2015.

PINHO, Isabel; REGO, Armenio; CUNHA, Miguel Pina. Improving knowledge management processes: a hybrid positive approach. Journal of Knowledge Management, v. 16, n. 2, 2012, p. 215-242.

PDI. Plano de desenvolvimento institucional do Instituto Federal de Educação, Ciência e Tecnologia do Rio Grande do Norte (2014-2018). Natal: IFRN, 2014.

SERENKO, Alexander. Meta-analysis of scientometric research of knowledge management: discovering the identity of the discipline. Journal of Knowledge Management, v. 17, n. 5, 2013, p. 773-812.

SILVA, Thaís Santos Silva; LIMA, Afonso Augusto Teixeira de Freitas de Carvalho; GOMIDE, Camila Sant Anna. Inovação na administração pública: um meta estudo dos anais do Enanpad. Revista Capital Científico-Eletrônica. Guarapuava, v. 15, n. 1, 2017, p. 118-138.

SCHLESINGER, Cristina Costa Barros et al. Gestão do conhecimento na administração pública. Curitiba: Imap, 2008.

TORUGSA, Nuttaneeya; O'DONOHUE, Wayne. Progress in innovation and knowledge management research: From incremental to transformative innovation. Journal of Business Research, v. 69, n. 5, 2016, p. 1610-1614.

VAN WAVEREN, Corro; OERLEMANS, Leon; PRETORIUS, Tinus. Refining the classification of knowledge transfer mechanisms for project-to-project knowledge sharing. South African Journal of Economic and Management Sciences, v. 20, n. 1, 2017, p. 1-16. 
WANG, Sheng; NOE, Raymond A; WANG, Zhong-Ming. Motivating knowledge sharing in knowledge management systems: A quasi-field experiment. Journal of Management, v. 40, n. 4, 2014, p. 978-1009.

Gustavo Moura Cavalcanti is master in Administration from the Potiguar University

Orcid: http://orcid.org/0000-0001-9859-908X

Address: Avenida Engenheiro Roberto Freire, 2184 - 59082-902 - Natal - RN Brazil.

E-mail: gustavo.moura@ifrn.edu.br.

Lydia Maria Pinto Brito is professor at the Potiguar University, Post-Graduate Program in Administration.

Orcid: http://orcid.org/0000-0003-1514-9476

Address: Avenida Engenheiro Roberto Freire, 2184 - 59082-902 - Natal - RN Brazil.

E-mail: Iydiampbrito@yahoo.com.br.

Ahiram Brunni Cartaxo de Castro is doctoral student in Business administration at the University Potiguar.

Orcid: http://orcid.org/0000-0001-5952-953X.

Address: Avenida Engenheiro Roberto Freire, 2184 - 59082-902 - Natal - RN Brazil.

E-mail: brunnicastro@hotmail.com.

Arthur William Pereira da Silva is doctoral student in Business administration at the University Potiguar.

Orcid: http://orcid.org/0000-0002-4515-6581.

Address: Avenida Engenheiro Roberto Freire, 2184 - 59082-902 - Natal - RN Brazil.

E-mail: arthurwilliamadm@hotmail.com.

Recebido em 20 de janeiro de 2020.

Aceito em 16 de abril de 2020.

(c) (i) 